\title{
Women Scientists Are the Rule Rather Than the Exception
}

\author{
A new book shines a spotlight on the historical participation of women in \\ science, showing that women scientists are not anomalies, even if \\ textbooks paint them that way.
}

By Katherine Wright

$\prod$ he science sections of bookstores are awash with biographies that recount the lives of past women scientists. These books typically highlight women from the same short list, which includes the physicists Marie Curie, Rosalind Franklin, and Jocelyn Bell Burnell.

While no one would dispute that these women made important contributions to science, focusing on the same few names over and over again reinforces the impression that science is-and always has been-an occupation for men with only the occasional women interlopers, says the writer and historian Leila McNeill. McNeill hopes her new book, which she coauthored with the writer and historian Anna Reser, will change that narrative by showing that women have always

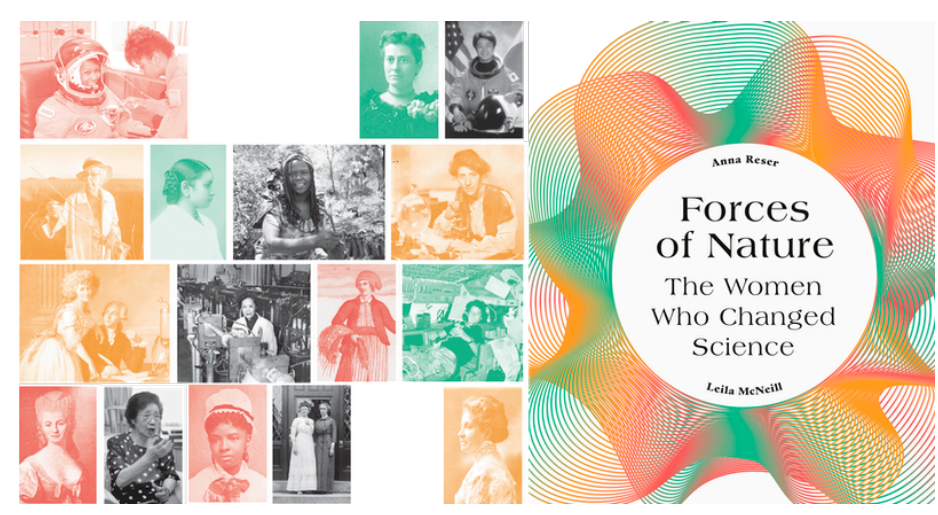

A new book by Anna Reser and Leila McNeill hopes to change the narrative that women are interlopers in science.

Credit: Frances Lincoln Publishing, an imprint of The Quarto Group practiced science and in much larger numbers than most textbooks portray. "Recovering the place of women in science benefits from our informed assumption that they existed and that their scientific practices... were held in the same high regard as those of their male contemporaries," McNeill and Reser write in the book.

Their book, Forces of Nature, The Women Who Changed Science, tracks the participation of women in science from the ancient Egyptian and Greek civilizations through to the modern day. The scientific contributions of women are interwoven with pertinent cultural and historical details that highlight the barriers that women have faced in conducting science, the creative ways they have found for overcoming those barriers, and the changes their efforts have sparked in society.

For example, Latin was still the scholarly language of choice in Europe until the late 1600s. That tradition denied access to the latest advances to those without an education-largely the poor and women, who in most places didn't receive a formal education until relatively recently. Some women surmounted this obstacle through birth or marriage, learning from their fathers, husbands, and brothers. The astronomer Maria Cunitz did exactly that and went on to publish in 1650 her astronomical calculations of planet motions in German, initiating a switch to publishing in other tongues that widened entry to science.

Gaining access to universities and laboratory tools has also been a barrier to women studying science, but that has sparked creativity in how they conducted science. McNeill and Reser document that many women performed experiments in their homes, such as the chemist Marie-Anne Paulze, who worked in 


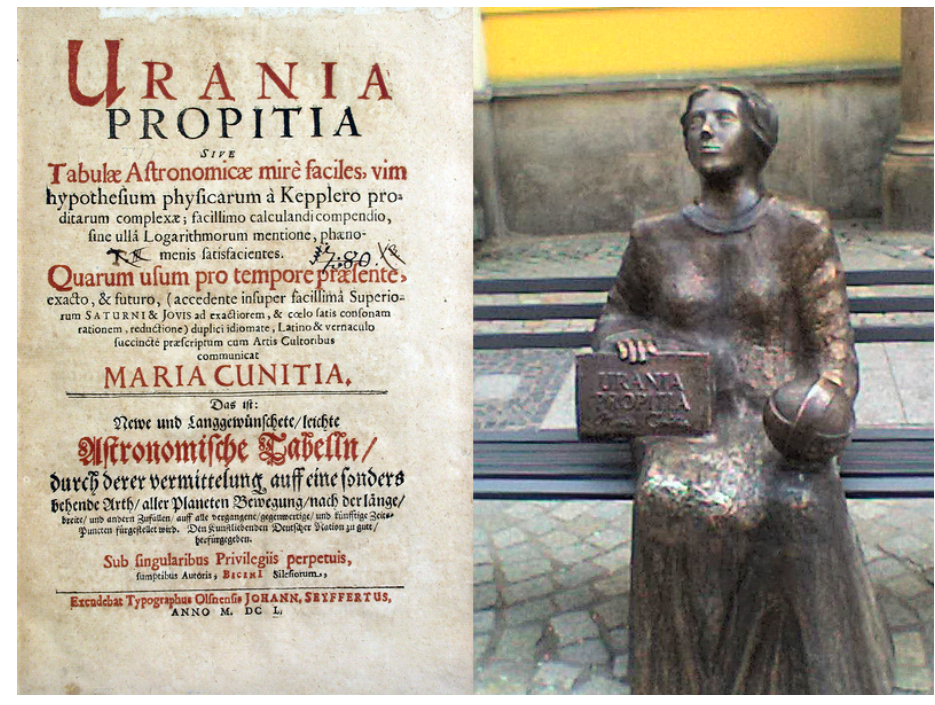

Maria Cunitz's book Urania Propitia was published in both Latin and German.

Credit: History of Science Collections, University of Oklahoma Libraries/Sueroski/Wikimedia

a home lab alongside her husband, until he was killed in 1794. She then completed their experiments and published their results. (She chose to publish only under his name-women scientists typically didn't put their names on their works at this time.)

And then there was Harriet Gillespie, a woman from New Jersey, who turned her whole house into a lab, testing out new technologies and methods for reducing motion in household chores. Her article, published in the US edition of the magazine Good Housekeeping in 1913, inspired countless women to engage in domestic engineering and science by optimizing the activities of the home. "By incorporating scientific ideas and practices into their everyday lives, many women participated in science on their own terms, creating space for themselves and others at the margins of science," McNeill and Reser write.

I was fascinated with the historical and contextual journey, which is something commonly lacking in books or articles that focus on the "best" women scientists and their accomplishments. I also appreciated that McNeill and Reser have charted the contributions of "everyday" women scientists as well as the big shots. McNeill says that this framing was intentional. By focusing less on individual achievements and more on what was happening in the science community as a whole at a given point in history, "women scientists don't look like anomalies," she says. "Rather, they look like people who were working in science to the best of their abilities."

The book is littered with beautiful images and has a coffee-table quality that has given it pride of place on my bookshelf. My only wish for this book is that I had encountered it much earlier in my life. Had the text been part of my curriculum as an undergraduate physics student, where sadly I learned only of the discoveries of men in my field, my view of women's historical contributions to science would have been very different.

Nowadays, school curriculums make an effort to shine a light on women like Marie Curie and Vera Rubin, but men still dominate. A fuller picture would show that the contributions of men and women to science have been intertwined throughout the ages.

People are hungry to hear more diverse stories about both the history of science and the individuals involved in its everyday workings, McNeill says. It was time to "serve that up." She adds, "when given the opportunities, resources, and support to succeed, and when their knowledge is valued, women have always had the power to shape science itself."

Forces of Nature, The Women Who Changed Science will be available from booksellers on May 4, 2021. (The original date of April 20 was pushed back due to delays caused by the blockage in the Suez Canal.)

Katherine Wright is the Deputy Editor of Physics. 